\title{
Frequency and Position of the Mental Foramen in Panoramic X-rays: Literature Review
}

\author{
Frecuencia y Posición del Foramen Mental en Radiografías Panorámicas: Revisión Bibliográfica
}

\author{
Francisco Ceballos ${ }^{1}$; Javier González ${ }^{1}$; Pamela Hernández ${ }^{1}$; Naira Deana² \& Nilton Alves ${ }^{1,3}$
}

CEBALlOS, F.; GONZÁLEZ, J.; HERNÁNDEZ, P.; DEANA, N. \& ALVES, N. Frequency and position of the mental foramen in panoramic X-rays: Literature review. Int. J. Morphol., 35(3):1114-1120, 2017.

SUMMARY: The mental foramen (MF), located in the body of mandible in the region below the inferior premolars, is the anatomical structure through which the mental neurovascular bundle emerges. The MF can be seen clearly in panoramic X-rays. The object of the present study was to carry out a literature review in order to identify the frequency and position of the MF in panoramic Xrays. We looked for articles in the SCiELO, Pubmed, Scopus, LILACS, Web of Science and EBSCOhost databases, for the years 2006 to 2016. The key words used were "mental foramen", "mandibular canal", "inferior alveolar nerve", "anatomy" and "panoramic X-ray". Once the articles had been selected, an analysis was made of their methodological quality; poor-quality articles were excluded. In each article the frequency and position of the MF in each hemi-mandible was analyzed. We found 82 articles, of which 20 were retained after application of the exclusion criteria. The MF was found in 4,824 hemi-mandibles (95.2\%), with greater presence on the left side (50.29 $\%)$ than the right $(49.71 \%)$. The MF is most commonly located between the apices of the inferior premolars (42.22\%), coincident with the root of the second inferior premolar $(33.98 \%)$ or distal of the root of the second inferior premolar $(10.98 \%)$. The MF is a very frequent anatomical structure. Knowledge of its location is fundamental for reducing the risk of accidents and unexpected events during clinical and surgical manoeuvres.

KEY WORDS: Mental foramen; Mandibular canal; Inferior alveolar nerve; Panoramic X-ray; Anatomy.

\section{INTRODUCTION}

The mental foramen (MF) is an anatomical structure located in the body of mandible through which the mental nerve emerges. The mental nerve innervates the skin and mucous of the lower lip, the skin of the chin and the mucous of the vestibular face of the inferior incisor, canine and premolar teeth (Alves \& Cândido, 2016). The mental artery and vein also pass through the MF (Moore et al., 2013), being responsible respectively for the irrigation and drainage of the region (Alves \& Cândido). Damage to the inferior alveolar nerve is one of the most serious complications in mandibular surgery (Soheilifar et al., 2016), and can cause changes in sensitivity and temporary or permanent damage (Amorim et al., 2008).

In X-rays, the MF appears as a radiolucent area in the region of the inferior premolars, sometimes coinciding with the root of one of them. Panoramic X-rays (PX) offer a great advantage over intraoral X-rays in the examination of hard and soft tissues, especially because of the continuity and extent of the area seen, and the rapidity with which the image is produced. Viewing the body of mandible as a whole offers greater precision in locating the MF in both the vertical and horizontal planes (Gupta et al., 2015).

Knowledge of the MF and the structures which emerge from it and surround it is fundamental for minimising the risk of complications and optimizing surgical manoeuvres in the region.

The object of the present study was to carry out a review of the literature in order to identify the frequency and position of the MF in PX.

\footnotetext{
${ }^{1}$ Faculty of Dentistry, Universidad de La Frontera, Temuco, Chile.

${ }^{2}$ Máster Program in Dentistry, Faculty of Dentistry, Universidad de La Frontera, Temuco, Chile.

${ }^{3}$ Applied Morphology Research Center (CIMA), Faculty of Dentistry, Universidad de La Frontera, Temuco.
} 


\section{MATERIAL AND METHOD}

Protocol and Records. A group of three operators carried out a literature search in two databases each, specified in the search strategy. Each article found was analysed under the inclusion and exclusion criteria and the articles selected were recorded in a table with the author(s), year of publication, title, study population, $\mathrm{n}$ of the sample, age, sex and the MF data found (frequency, position, shape and appearance in X-ray).

\section{Selection criteria}

Population: Adult patients with no pathological condition. Intervention: Analysis of panoramic X-rays.

Comparison: None.

Results: Establish the parameters for the presence and position of the MF.

Study design: Cross sectional, retrospective.

Inclusion criteria: Studies were included which used panoramic X-ray as the diagnostic method for assessing the frequency and position of the MF in patients of both sexes, aged 9 to 86 years, including articles in Spanish, English and Portuguese.

Exclusion criteria: The following exclusion criteria were applied: (1) articles which did not analyze panoramic Xrays; (2) articles in which the patients suffered local pathologies; (3) articles in which the species analyzed was not human; (4) articles which did not refer to the subject of interest (analysis of the MF).

Search strategy. In the present literature review we looked for articles in the SCiELO, Pubmed, Scopus, LILACS, Web of Science and EBSCOhost databases, for the years 2006 to 2016. The key words used were "mental foramen" AND "panoramic X-ray" AND "anatomy" OR "mandibular canal" AND "panoramic X-ray" AND "anatomy" OR "inferior alveolar nerve" AND "panoramic X-ray" AND "anatomy".
Study selection. In the first place the titles and abstracts of the articles were reviewed and duplicate studies were excluded; then all those which did not comply with the inclusion criteria were excluded. The whole text was examined in the case of articles with no abstract or insufficient information. The references of the articles included were examined carefully to identify additional studies.

Data collection. The data from each article selected were analyzed to obtain: sample size, population, sex, and frequency; position, shape and X-ray appearance of MF. The sample size was the number of panoramic $\mathrm{X}$-rays analyzed in each article.

Evaluation of methodological quality. To assess the methodological quality of each article we used the points system of Cericato et al. (2015), modified, using a total of 11 criteria (Table I). The sum of the scores for each criterion was between minimum 0 and maximum 14 . The articles were classified into 3 categories according to their total score: articles with 0 to 7 points were classified as low quality; 8 to 11 moderate quality and 12 to 14 as high quality. We also analyzed the percentage of studies which complied with each criterion analyzed. Articles classified as low quality were excluded for poor methodology. Table 1 shows the criteria proposed by Cericato et al. modified, discarding only the criterion "use of a control group", since it did not apply to this study.

\section{RESULTS}

A flow chart for the selection of articles at each stage of the review is shown in Figure 1. We found 82 articles in the various databases: 26 in Scielo, 20 in PubMed, 20 in Scopus, 1 in LILACS, 1 in WOS and 14 in EBSCOhost.

Table I. Criteria used for methodological analysis of the studies.

\begin{tabular}{lc}
\hline \multicolumn{1}{c}{ Selection criterion } & Score \\
\hline 1. The abstract clearly presents the object of the study, the methodology, the results and the conclusions. & 1 point \\
2. The study states the object clearly and precisely. & 1 point \\
3. The ethical considerations of the investigation are cited in the text. & 1 point \\
4. The type of study is described. & 1 point \\
5. The study reports how the sample was calculated. & 2 points \\
6. The inclusion and exclusion criteria are described (1 point each). & 2 points \\
7. The study design is appropriate (randomisation and bias). & 2 points \\
8. The statistical tests are described. & 1 point \\
9. The $p$-values are cited. & 1 point \\
10. The study results are expressed clearly and precisely. & 1 point \\
11. The study limitations are discussed. & 1 point \\
\hline
\end{tabular}


CEBALlOS, F.; GONZÁLEZ, J.; HERNÁNDEZ, P.; DEANA, N.; \& ALVES, N. Frequency and position of the mental foramen in panoramic X-rays: Literature review.

Int. J. Morphol., 35(3):1114-1120, 2017

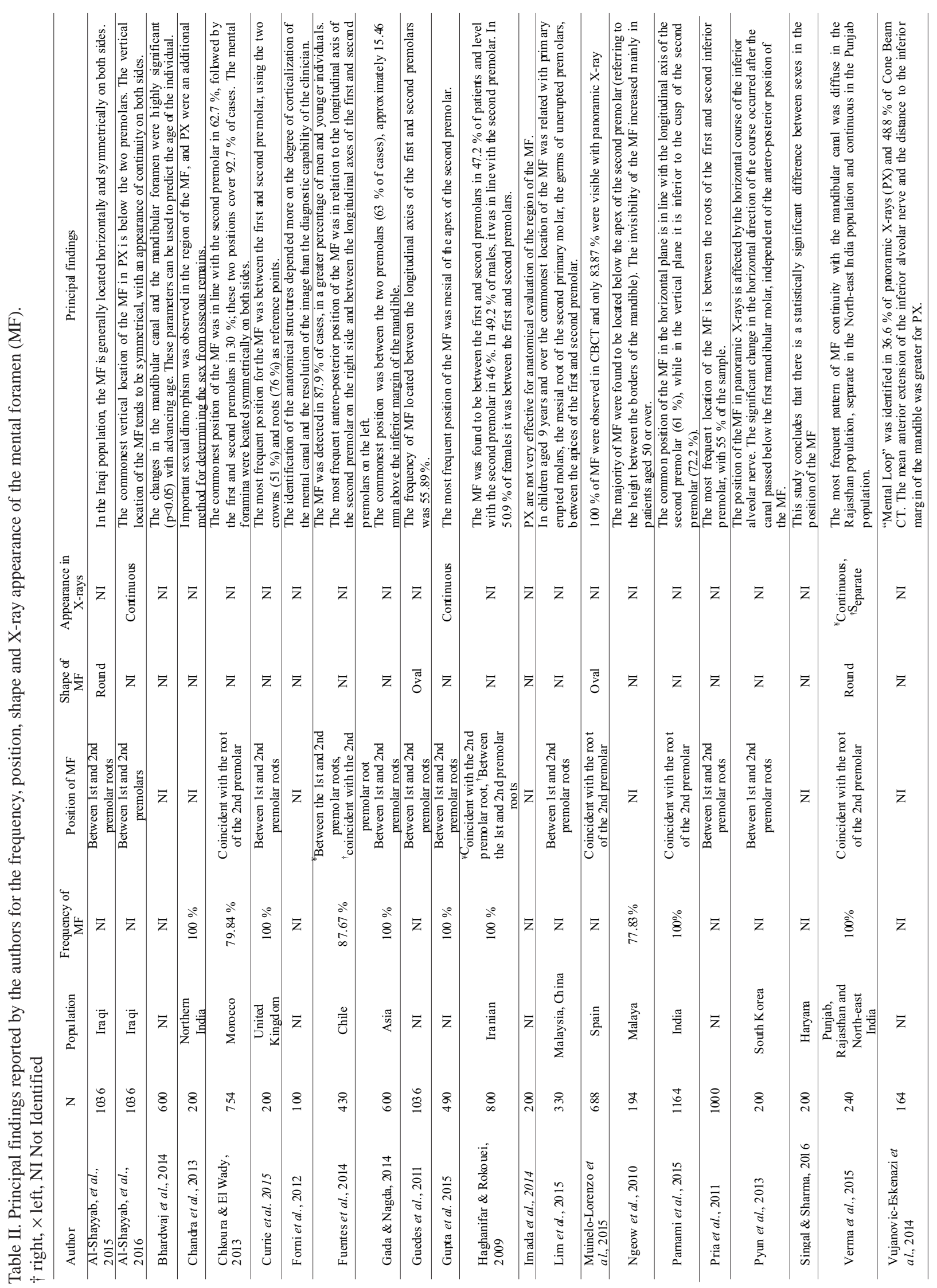




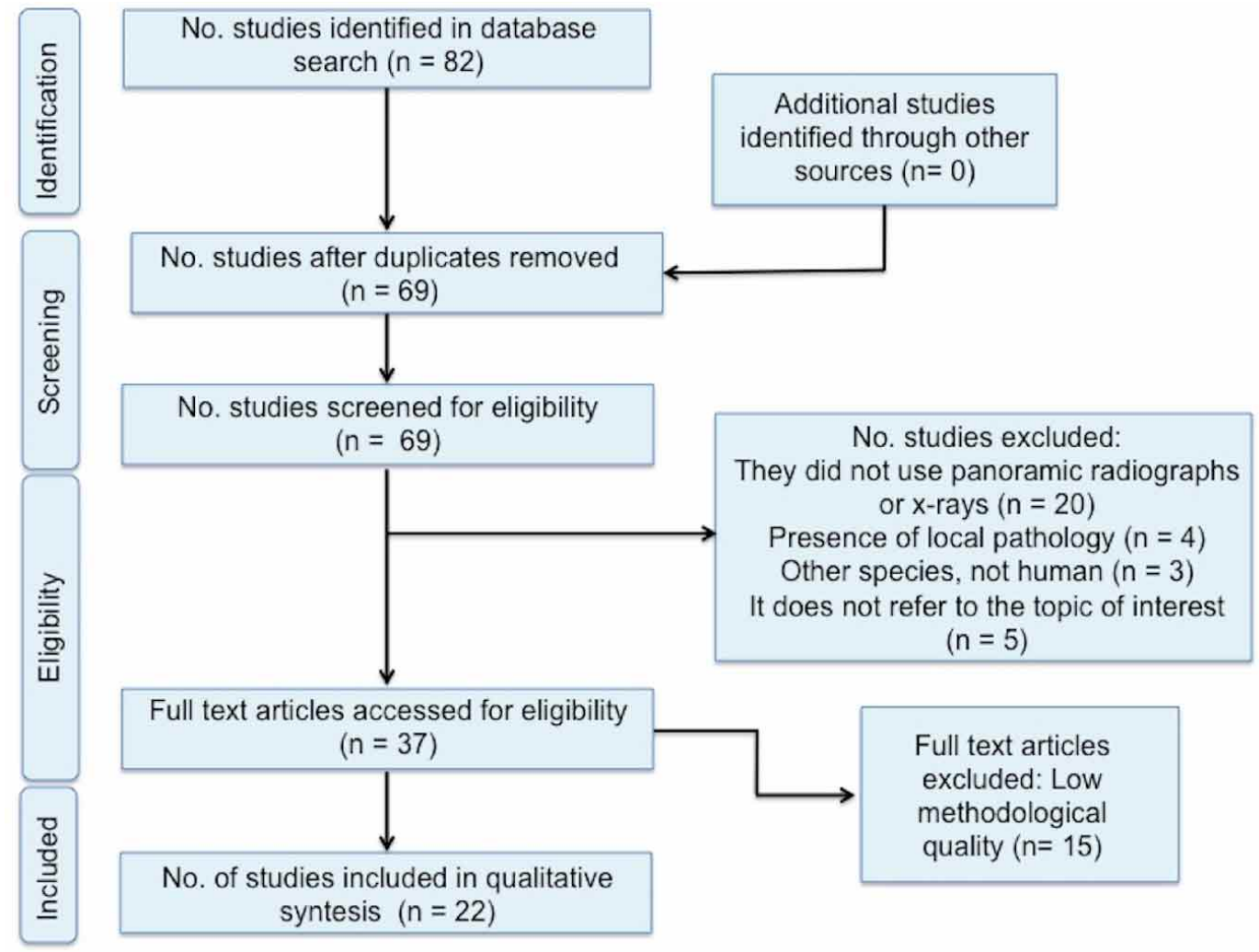

Fig. 1. Flow diagram of the article selection process.

After excluding duplicates, we selected 69 articles. After application of the inclusion/exclusion criteria, 37 complete texts were selected and analysed, 15 of which were excluded for poor methodology. The qualitative analysis included 22 articles. Of the 22 articles, only 10 analysed the presence of the MF and 14 its position. The principal findings of the articles included are shown in Table II.

Evaluation of methodological quality. Each article was awarded a score based on the criteria analysed. Of all the articles studied, five obtained maximum 13 points (13.6 $\%)$ and two were awarded 12 points (5.4\%), giving seven high quality articles $(19 \%)$. There were thirteen articles awarded scores between 8 and 11 points, classified as moderate quality $(35.1 \%)$. The remaining articles (45.9 $\%)$ obtained below 8 points and were classified as low quality.

The percentage of articles for each item analysed is shown in Figure 2. We observed that the principal weaknesses of the studies were that they did not discuss the ethical aspects of the research (49\%) (criterion 3), did not describe the type of study (68\%) (criterion 4), the design did not include (or the article did not describe) the randomization and the bias (49\%) (criterion 7), and that the study limitations were not discussed (49\%) (criterion 11).

Frequency analysis. Of a total of 5,071 hemi-mandibles analysed, the MF was found in 4,824 (95.13\%), with 50.29 $\%$ of foramina in the left hemi-mandible and $49.71 \%$ in the right hemi-mandible. In the left hemi-mandible the presence of the MF was recorded in $95.70 \%$ of cases, whereas in the right hemi-mandible it was present in $94.56 \%$.

Analysis of MF position. The 14 articles collected analysed a total of 8,906 hemi-mandibles. In the majority of cases the MF was located between the roots of the first and second inferior premolar; the least frequent location was mesial of the apex of the first inferior premolar. The frequencies of the positions of the MF diminish in the order: coincident with the apex of the second inferior premolar; distal of the apex of the second inferior premolar; coincident with the apex of the first inferior premolar. Moreover two situations were found which are not described in the proposed classification of position, namely a location coincident with the first inferior molar and another unclassified due to discontinuity of the premolar zone; these were assigned to position 6 (other position) (Fig. 3). 


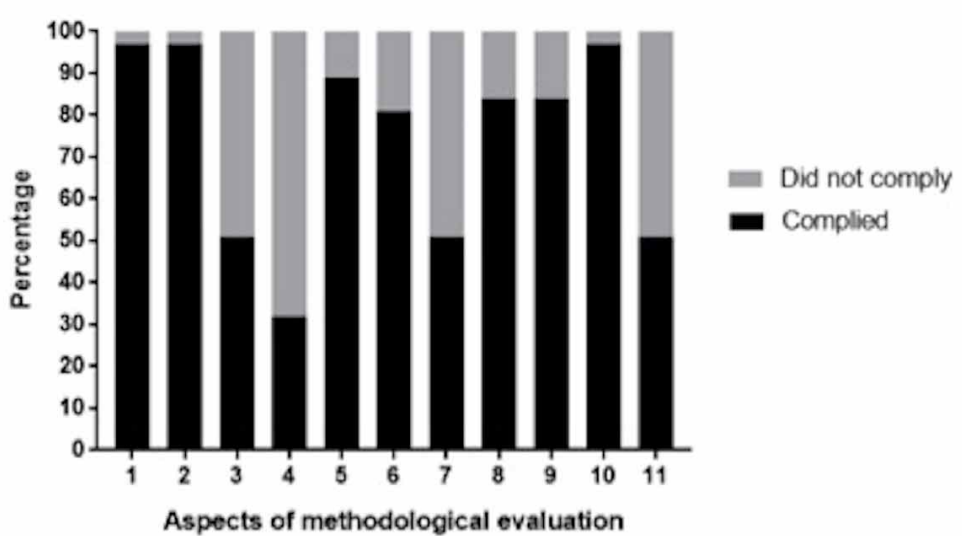

Fig. 2. Percentage of articles complying with each criterion used for methodological evaluation.

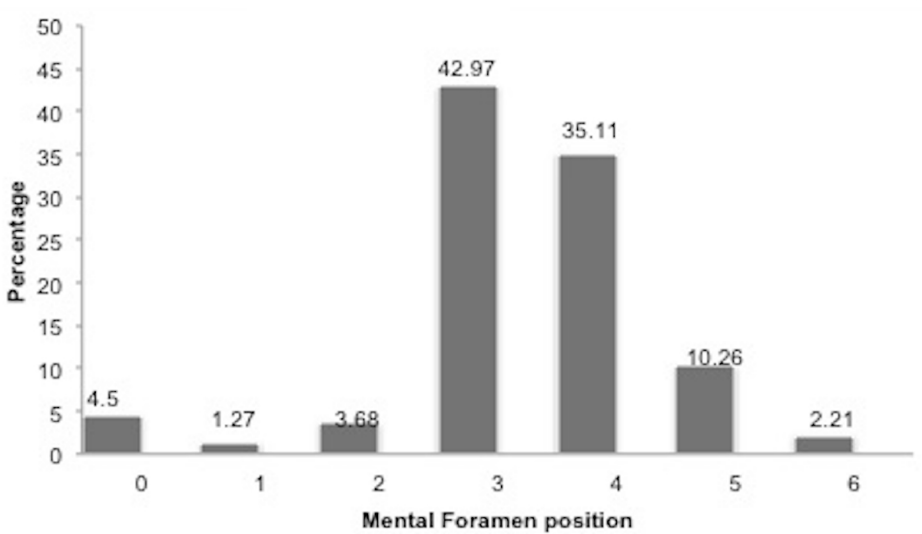

Fig. 3. Position of the mental foramen by total number of of hemi-arches. 0 Mental foramen absent; 1 Mesial of the apex of the first inferior premolar (3.4 or 4.4); 2 Coincident with the apex of the first inferior premolar (3.4 or 4.4); 3 Between the apices of first and second inferior premolars (3.4 and 3.5 or 4.4 and $3.5)$; 4 Coincident with the second inferior premolar (3.5 or 4.5); 5 Distal of the apex of the second inferior premolar (3.5 or 4.5); 6 Other position.

Males afemales

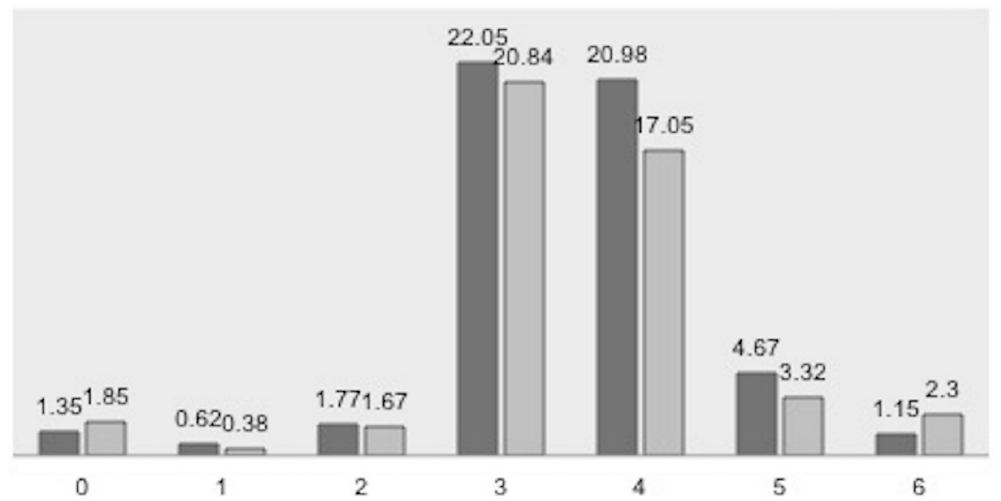

Fig. 4. Percentage of the position of the mental foramen by sex. 0 Mental foramen absent; 1 Mesial of the apex of the first inferior premolar (3.4 or 4.4); 2 Coincident with the apex of the first inferior premolar (3.4 or 4.4); 3 Between the apices of first and second inferior premolars (3.4 and 3.5 or 4.4 and 3.5); 4 Coincident with the second inferior premolar (3.5 or 4.5); 5 Distal of the apex of the second inferior premolar (3.5 or 4.5); 6 Other position.
In the analysis of position by sex (Figure 4), 5,033 hemi-mandibles were analyzed. In both male and female individuals the most frequent position was between the apices of the first and second inferior premolar, but the percentage in this position was higher in men than in women. The lowest number of cases for the position of the MF was mesial of the apex of the first inferior premolar, in both men and women, and again a higher percentage was recorded in men.

In women the other positions described diminished in the order: coincident with the apex of the second inferior premolar; distal of the apex of the first inferior molar; other position, and lastly coincident with the apex of the first inferior premolar. For men also the frequency of the position decreased in the order: coincident with the apex of the second inferior premolar; mesial of the apex of the first inferior molar; but here there was a difference from the findings in women since the next position was distal of the first inferior premolar, and other position was the least frequent.

\section{DISCUSSION}

The MF is frequently related with certain stages of maxillofacial surgery and it is important to identify and preserve its limits in periapical surgery, implants and orthognathic procedures (Al-Khateeb et al., 2007). The MF and its anatomical variations must be considered in order to allow clinical and surgical procedures to be carried out safely in the region (Imada et al., 2014).

Turning to the frequency of the MF in the PX, Fuentes et al. (2014), in a study of a Chilean population, concluded that the MF is visible in $87.9 \%$ of cases, with a higher percentage in men. Chkoura \& El Wady (2013), in a Moroccan population, described a frequency of $79.8 \%$, while Ngeow et al. (2010) found a visible MF in 77.8\% of cases in a Malay population.

According to the studies analysed, sex and age were comparable characteristics for presence of MF, with a higher percentage of visibility in men and at younger ages (Fuentes et al.). 
However other authors found no statistically significant differences between the sexes (Currie et al. (2015).

According to Currie et al., the most frequent position of the MF was between the first and second inferior premolar (76\%); in this they are supported by Al-Shayyab et al. (2015) (48.6\%), Gada \& Nagda (2014) (63\%), Guedes et al. (2011) (55.89\%), Gupta et al. (30.8\%), Haghanifar \& Rokouei (2009) (47.2 \%), Lim et al. (2015) (41.2 \%), Pyun et al. (2013) (72 $\%$ ) and Pria et al. (2011) (55\%). The second most frequent position was coincident with the root of the second premolar and the least frequent was mesial of the first premolar; these findings were corroborated by Chkoura \& El Wady, Fuentes et al., Parnami et al. (2015) and Verma et al. (2015).

In Caucasians the antero-posterior position of the MF was in the area between the long axes of the first and second mandibular premolars, followed by the position in line with the axis of the second inferior premolar. On this basis, these authors state that to carry out a nerve block in the region the needle should be placed opposite the second mandibular premolar, with a $95 \%$ chance of success. According to Green et al. (1987), the position of the MF in Caucasians is just anterior of the long axis of the second mandibular premolar, while it is further posterior in Mongoloid, Melanesian and Negroid ethnic groups. Ari et al. (2005), indicate that features like the location of the MF could be used not only to distinguish between populations from different geographical zones, but also between inhabitants of the same zone. On the left side the MF is mostly located between the longitudinal axes of the first and second premolars, however on the right side it is related to the longitudinal axis of the second premolar; this finding for the MF on the right side agrees with Parnami et al. (61 \%), Chkoura \& El Wady (62.7 \%), Muinelo-Lorenzo et al. (2015) (57.9\%), Verma et al. (45.2\%) and Fuentes et al. $(26.34 \%)$.

Currie et al. state that the position of the MF is usually symmetrical, in $62 \%$ of cases; this correlates with the findings of Al-Shayyab et al. (2015), who found symmetrical positioning of the MF in $78.4 \%$ of the cases analyzed.

The MF may present in different shapes: it was round in a majority of cases (55.8\%) according to Verma et al., corroborated by Al-Shayyab et al. (2015). This contradicts the findings of Muinelo-Lorenzo et al., who reported that the most frequently found shape was oval (73.1\%); and of Guedes et al., who reported that it was irregular $(62.7 \%)$.

Al-Shayyab et al. (2016), Gupta et al. and Verma et $a l$. , describe that the most frequent appearance in X-ray is as a continuation of the mandibular canal (MC), followed by appearance separately from the MC.
It should be noted that absence of the MF is very rare, occurring in around $0.06 \%$ (de Freitas et al., 1979). The MF was absent or could not be identified in $22.2 \%$ of cases according to Ngeow et al., and in $16.13 \%$ according to Muinelo Lorenzo et al. Previous studies have shown that panoramic $\mathrm{X}$-rays present satisfactory precision for identification of the MF and MC (Soheilifar et al.); however some authors assert that PX are not suitable for identifying the MF, and that other imaging techniques should be used in pre-surgery planning, such as cone beam computerized tomography (Muinelo-Lorenzo et al.). It should also be borne in mind that PX emit radiation, and although the emissions are lower than with other imaging techniques such as tomography, there is no justification for exposing a patient to radiation for the sole purpose of analyzing the position of the MF.

\section{CONCLUSIONS}

The MF is a very frequent anatomical structure, generally located below the inferior premolars. It is of great clinical importance, and detailed knowledge of its characteristics and anatomical variations is very important for avoiding complications and reducing the risk of accidents during clinical-surgical procedures in the region. Although PX present good precision in identification of the MF, clinical conditions may occur which require other imaging techniques for identification.

CEBALLOS, F.; GONZÁlEZ, J.; HERNÁNDEZ, P.; DEANA, N. \& ALVES, N. Frecuencia y posición del foramen mental en radiografías panorámicas: Revisión bibliográfica. Int. J. Morphol., 35(3):1114-1120, 2017.

RESUMEN: El foramen mental (FM), ubicado en el cuerpo de la mandíbula, inferiormente a la región de los dientes premolares inferiores, es la estructura anatómica por donde emerge el paquete vásculonervioso mental. El FM se logra visualizar con buena precisión en una radiografía panorámica. El objetivo del presente estudio fue realizar una revisión de la literatura para identificar la frecuencia y posición del FM en radiografías panorámicas. Se buscaron artículos en las bases de datos SCiELO, Pubmed, Scopus, LILACS, Web of Science y EBSCOhost, entre los años 2006 y 2016. Las palabras clave utilizadas fueron "foramen mental", "canal mandibular", "nervio alveolar inferior", "anatomía" y "radiografía panorámica". Tras la selección de los artículos se realizó un análisis de la calidad metodológica de los mismos, donde se excluyó artículos de baja calidad. Se analizó en cada artículo la frecuencia y posición del FM en cada hemimandíbula. Se encontraron 82 artículos, de los cuales quedaron sólo 20 al aplicar criterios de exclusión. El FM fue encontrado en 4824 hemimandíbulas (95,2 \%), siendo el lado izquierdo donde hubo mayor presencia de forámenes $(50,29 \%)$ en comparación al lado derecho $(49,71 \%)$. El FM se localiza entre los ápices de los premolares inferiores en $42,22 \%$, es coincidente con la raíz del segundo premolar inferior en $33,98 \%$, y es distal a la raíz del segundo premolar inferior en 10,98\%, siendo éstos los más relevantes. El FM es una estructura anatómica muy frecuente, ubicada en general inferiormente a los premolares inferiores. Es una estructura de gran importancia clínica, por ello el conocimiento detallado de sus características y variaciones anatómicas es muy im- 
portante para evitar complicaciones y disminuir el riesgo de accidentes durante procedimientos clínico-quirúrgicos en la región. Además, a pesar de que la RP presenta buena precisión en la identificación del FM hay condiciones clínicas que requieren otros métodos imagenológicos para su identificación.

PALABRAS CLAVE: Foramen mental; Canal mandibular; Nervio alveolar inferior; Radiografía panorámica; Anatomía.

\section{REFERENCES}

Al-Khateeb, T.; Al-Hadi Hamasha, A. \& Ababneh, K. T. Position of the mental foramen in a northern regional Jordanian population. Surg. Radiol. Anat., 29(3):231-7, 2007.

Al-Shayyab, M. H.; Alsoleihat, F.; Dar-Odeh, N. S.; Ryalat, S. \& Baqain, Z. $\mathrm{H}$. The mental foramen I: Radiographic study of the anterior-posterior position and shape in Iraqi population. Int. J. Morphol., 33(1):149-57, 2015.

Al-Shayyab, M. H.; Alsoleihat, F.; Dar-Odeh, N. S.; Ryalat, S. \& Baqain, Z. $\mathrm{H}$. The mental foramen II: Radiographic study of the superior-inferior position, appearance and accessory foramina in Iraqi population. Int. J. Morphol., 34(1):310-9, 2016.

Alves, N. \& Cândido, P. L. Anatomia para o Curso de Odontologia Geral e Específica. $4^{\mathrm{a}}$ ed. São Paulo, Gen-Santos, 2016.

Amorim, M. M.; Prado, F. B.; Borini, C. B.; Bittar, T. O.; Volpato, M. C.; Groppo, F. C. \& Caria, P. H. F. The mental foramen position in dentate and edentulous Brazilian's mandible. Int. J. Morphol., 26(4):981-7, 2008.

Ari, I.; Kafa, I. M.; Basar, Z. \& Kurt, M. A. The localization and anthropometry of mental foramen on late Byzantine mandibles. Coll. Antropol, 29(1):2336, 2005.

Bhardwaj, D.; Kumar, J. S. \& Mohan, V. Radiographic evaluation of mandible to predict the gender and age. J. Clin. Diagn. Res., 8(10):ZC66-9, 2014.

Cericato, G. O.; Bittencourt, M. A. \& Paranhos, L. R. Validity of the assessment method of skeletal maturation by cervical vertebrae: a systematic review and meta-analysis. Dentomaxillofac. Radiol., 44(4):20140270, 2015.

Chandra, A.; Singh, A.; Badni, M.; Jaiswal, R. \& Agnihotri, A. Determination of sex by radiographic analysis of mental foramen in North Indian population. J. Forensic. Dent. Sci., 5(1):52-5, 2013.

Chkoura, A. \& El Wady, W. Position of the mental foramen in a Moroccan population: A radiographic study. Imaging Sci. Dent., 43(2):71-5, 2013.

Currie, C. C.; Meechan, J. G.; Whitworth, J. M.; Carr, A. \& Corbett, I. P. Determination of the mental foramen position in dental radiographs in 18-30 year olds. Dentomaxillofac. Radiol., 45(1):20150195, 2015.

de Freitas, V.; Madeira, M. C.; Toledo Filho, J. L. \& Chagas, C. F. Absence of the mental foramen in dry human mandibles. Acta Anat. (Basel), 104(3):353-5, 1979.

Forni, A.; Sánchez-Garcés, M. A. \& Gay-Escoda, C. Identification of the mental neurovascular bundle: a comparative study of panoramic radiography and computer tomography. Implant Dent., 21(6):516-21, 2012.

Fuentes, R.; Cantin, M.; Navarro, P.; Borie, E.; Beltran, V. \& Bucchi, C. Characterization of anatomical structures using panoramic radiographs: The mental foramen. Int. J. Morphol., 32(4):1423-9, 2014.

Gada S. K. \& Nagda, S. J. Assessment of position and bilateral symmetry of occurrence of mental foramen in dentate asian population. J. Clin. Diagn. Res., 8(2):203-5, 2014

Green, R. M. The position of the mental foramen: a comparison between the southern (Hong Kong) Chinese and other ethnic and racial groups. Oral Surg. Oral Med. Oral Pathol., 63(3):287-90, 1987.

Guedes, O. A.; Rabelo, L. E. G., Porto, O. C. L.; Alencar, A. H. G. \& Estrela, C. Radiographic evaluation of the position and shape of mental foramen in a Brazilian subpopulation. Rev. Odontol. Bras. Cent., 20(53):160-5, 2011.

Gupta, V.; Pitti, P. \& Sholapurkar, A. Panoramic radiographic study of mental foramen in selected dravidians of south Indian population: A hospital based study. J. Clin. Exp. Dent., 7(4):e451-6, 2015.

Haghanifar, S. \& Rokouei, M. Radiographic evaluation of the mental foramen in a selected Iranian population. Indian J. Dent. Res., 20(2):150-2, 2009.

Imada, T. S.; Fernandes, L. M.; Centurion, B. S.; de Oliveira-Santos, C.; Honório, H. M. \& Rubira-Bullen, I. R. Accessory mental foramina: prevalence, position and diameter assessed by cone-beam computed tomography and digital panoramic radiographs. Clin. Oral Implants Res., 25(2):e94-9, 2014

Lim, M. Y.; Lim, W. W.; Rajan, S.; Nambiar, P. \& Ngeow, W. C. Age-related changes in the location of the mandibular and mental foramen in children with Mongoloid skeletal pattern. Eur. Arch. Paediatr. Dent., 16(5):397407, 2015 .

Moore, K. L.; Dalley, A. F. \& Agur, A. M. R. Anatomía con Orientación Clínica. $7^{\text {th }}$ ed. Philadelphia, Wolters Kluwer, Lippincott Williams \& Wilkins, 2013.

Muinelo-Lorenzo, J.; Suárez-Quintanilla, J. A.; Fernández-Alonso, A.; VarelaMallou, J. \& Suárez-Cunqueiro, M. M. Anatomical characteristics and visibility of mental foramen and accessory mental foramen: Panoramic radiography vs. cone beam CT. Med. Oral Patol. Oral Cir. Bucal, 20(6):e707-14, 2015.

Ngeow, W. C.; Dionysius, D. D.; Ishak, H. \& Nambiar, P. Effect of ageing towards location and visibility of mental foramen on panoramic radiographs. Singapore Dent. J., 31(1):15-9, 2010.

Parnami, P.; Gupta, D.; Arora, V.; Bhalla, S.; Kumar A. \& Malik, R. Assessment of the horizontal and vertical position of mental foramen in Indian population in terms of age and sex in dentate subjects by pano-ramic radiographs: A retrospective study with review of literature. Open Dent. J., 9:297-302, 2015.

Pria, C. M.; Masood, F.; Beckerley, J. M. \& Carson, R. E. Study of the inferior alveolar canal and mental foramen on digital panoramic images. $J$. Contemp. Dent. Pract., 12(4):265-71, 2011.

Pyun, J. H.; Lim, Y. J.; Kim, M. J.; Ahn, S. J. \& Kim, J. Position of the mental foramen on panoramic radiographs and its relation to the horizontal course of the mandibular canal: a computed tomographic analysis. Clin. Oral Implants Res., 24(8):890-5, 2013.

Singal, K. \& Sharma, S. Gender determination by mental foramen using linear measurements on radiographs: A study in Haryana population. Indian J. Forensic Med. Toxicol., 10(1):44-9, 2016.

Soheilifar, S.; Bidgoli, M.; Shokri, A.; Faradmal, J.; Kafilzadeh, S.; Eyvazi, P. \& Nikkhah, M. Panoramic radiographic study of mandibular canal and mental foramen in a selected Iranian population. SRM J. Res. Dental Sci., 7(4):209-13, 2016.

Verma, P.; Bansal, N.; Khosa, R.; Verma, K. G.; Sachdev, S. K.; Patwardhan, N. \& Garg, S. Correlation of radiographic mental foramen position and occulusion in three different Indian populations. West Indian Med. J., 64(3):269-74, 2015.

Vujanovic-Eskenazi, A.; Valero-James, J. M.; Sánchez-Garcés, M. A. \& GayEscoda, C. A retrospective radiographic evaluation of the anterior loop of the mental nerve: comparison between panoramic radiography and cone beam computerized tomography. Med. Oral Patol. Oral Cir. Bucal, 20(2):e239-45, 2015.

\section{Corresponding author:}

Nilton Alves

Faculty of Dentistry

Universidad de La Frontera

1145 Avda. Francisco Salazar

P.O. Box 54-D

Temuco - CHILE

Received: 17-05-2017

Accepted: 05-07-2017

E-mail: nilton.alves@ufrontera.cl 